\title{
OPTIMALISASI INTERMEDIASI DAN PEMBIAYAAN BMT MENUJU PEMBERDAYAAN EKONOMI MASYARAKAT
}

\author{
Fahrur Ulum \\ Universitas Islam Negeri Sunan Ampel Surabaya, Indonesia \\ E-mail: ulumfahrur@yahoo.com
}

\begin{abstract}
This article seeks to discuss the economic empowerment of society through the optimalization of BMT's function of intermediating and financing. Using a descriptive and qualitative approach, this article reveals that the success of economic empowerment should be supported by strategy, tactics and stepping. The program should also be implemented through segmentation and training of clients, providing human resources that understand the vision and mission of empowerment, optimizing BMT's function of intermediating, and providing a coordinated tool of saving. Intermediation is conducted through developing economic potentials of Muslim community (ummah), improving the quality of human resources, mobilizing societal resources, bridging the relation between the rich and the poor and between the fund owners and users, coaching and balancing in terms of financial support.
\end{abstract}

Keywords: Empowerment; intermediation; financing.

\section{Pendahuluan}

Sejak awal pendiriannya, kemunculan Bayt al-Mâl wa al-Tamwîl (BMT) diharapkan oleh banyak kalangan mampu menunjang pemberdayaan ekonomi masyarakat. BMT sebagai lembaga keuangan mikro diyakini mampu meningkatkan perekonomian kaum miskin dan menunjang pembangunan ekonomi. ${ }^{1}$ Apalagi BMT mulai banyak beroperasi di wilayah pedesaan. ${ }^{2}$ Daerah pedesaan biasanya menjadi

1 Mohammed El-Komi dan Rachel Groson, "Experiments in Islamic Microfinance", Journal of Economic Behavior and Organization, Vol. 83, No. 2 (2012), 1.

${ }^{2}$ Asosiasi BMT se-Indonesia (ABSINDO) memrogramkan satu desa satu BMT. Itu artinya akan segera dibuka sebanyak 8.206 BMT. Jumlah BMT pada tahun 2010 saja sekitar 4.000 BMT yang beroperasi di Indonesia yang terus dikembangkan secara masif. Jumlah BMT/KJKS per April 2012 adalah sekitar 4.117 unit dengan jumlah anggota sekitar 762 ribu anggota dan total asetnya mencapai Rp 5 triliun-Rp 8 triliun. Selengkapnya dapat dibaca dalam Nyadin, "Prospek Bisnis di Koperasi Jasa 
sasaran bagi rentenir dengan memanfaatkan sulitnya akses keuangan serta tingkat pendidikan dan ekonomi yang masih rendah.

Secara sosial BMT juga mempunyai potensi meningkatkan harkat dan martabat nasabahnya dengan pembinaan melalui komunitaskomunitas keagamaan, sosial dan kemasyarakatan. Beberapa penulis seperti el-Gamal ${ }^{3}$, al-Harran ${ }^{4}$, Akhtar $^{5}$, Dhumale, dan Sapcanin ${ }^{6}$ percaya terhadap potensi lembaga keuangan sharî́ah, termasuk BMT dalam peranannya sebagai intermediasi sosial dalam memenuhi kebutuhan masyarakat miskin yang sering terabaikan oleh perbankan konvensional.

Pemberdayaan ekonomi masyarakat yang dilakukan oleh BMT disadari dan didukung oleh berbagai pihak, mulai dari pemerintah, para praktisi, para ilmuwan, serta lembaga-lembaga inkubasi dan lembaga swadaya masyarakat lainnya. Misalnya, pemerintah telah mengeluarkan UU perkoperasian, yang termasuk di dalamnya mengatur tentang BMT.

Beberapa pemikir dan pemerhati BMT seperti Huda dan Heykal juga berpendapat bahwa fungsi BMT adalah: a). Menghimpun dan menyalurkan dana dari masyarakat, b). Pencipta dan pemberi liquiditas, c). Sumber pendapatan, d). Pemberi informasi kepada masyarakat mengenai risiko keuntungan dan peluang lembaga tersebut, e). Sebagai lembaga keuangan yang memberikan pembiayaan usaha kecil, mikro, dan menengah, f). Mengidentifikasi, memobilisasi dan mengorganisasi, mendorong dan mengembangkan potensi ekonomi anggota, dan g) Menggalang dan memobilisasi potensi

Keuangan Sharî‘ah Baitul Mal Wa Tamwil dan Peluang Kerja Bagi Alumni Program Ekonomi Sharî‘ah", Makalah dipresentasikan di IAIN Sunan Ampel Surabaya, 27 Desember 2011.

3 Mahmoud A. el-Gamal, Islamic Finance: Law, Economic, and Practice (Cambridge: Cambridge University Press, 2006), 153-163.

4 S. Al-Harran, "Islamic Finance Needs A New Paradigm", New Horizon, Vol. 48 (Feb, 1990), 7-9.

5 M. R. Akhtar, "Practice and Prospects of Musharaka Financing for Small Entreprise in Pakistan”, Journal of Islamic Banking in Finance, Vol. 13 No. 3 (1996), 7 27.

6 R. Dhumale dan A. Sapcanin, An Aplication of Islamic Banking Principles to Microfinance (United Nations Development Program, Regional Bureau for Arab States, New York, 1998). 
masyarakat dalam rangka meningkatkan potensi kesejahteraan anggota.

Namun dalam aplikasinya, pemberdayaan yang dilakukan oleh BMT selama ini belum sepenuhnya menuai hasil maksimal. Seringkali pembiayaan justru menimbulkan beban bagi nasabah sehingga semakin jauh dari pemberdayaan. Dengan demikian, telah terjadi gap antara fenomena konseptual dengan fenomena praktis, di mana semangat awal dan tujuan awal pendirian BMT adalah untuk menyejahterakan masyarakat melalui pemberdayaan ekonomi masyarakat, namun disinyalir dalam realisasinya semakin jauh dari harapan.

Artikel ini menjawab persoalan bagaimana pemberdayaan ekonomi masyarakat yang dilakukan oleh BMT dengan mengoptimalkan fungsi intermediasi BMT dan mekanisme pembiayaan yang dijalankannya? Penelitian ini dilakukan di BMT ArRidho, Desa Gondang Kecamatan Tugu Kabupaten Trenggalek. BMT Ar-Ridho dinilai berhasil karena memiliki aset yang cukup besar untuk ukuran BMT di desa dan memiliki omzet yang cukup besar pula. Aset BMT Ar-Ridho saat ini Rp 10.542.423.820,00 dengan omzet rata-rata Rp 115.000.000,00 per bulan. ${ }^{8}$ Selain itu BMT ArRidho juga memiliki nasabah yang cukup besar jika dibandingkan dengan BMT-BMT lainnya di Kabupaten Trenggalek. Jumlah nasabah BMT Ar-Ridho saat ini 4.918 orang dan 3.170 orang merupakan nasabah yang masih aktif. ${ }^{9}$ Besarnya aset, omzet serta jumlah nasabah dapat dijadikan sebagai salah satu indikasi keberhasilan BMT ArRidho. BMT Ar-Ridho juga dinilai berhasil secara kualitas karena memiliki arah pemberdayaan ekonomi masyarakat sejak awal mula pendiriannya. BMT Ar-Ridho memaksimalkan pembiayaan dengan menggunakan mekanisme-mekanisme kreatif sehingga mampu mengangkat perekonomian masyarakat sekitar. BMT Ar-Ridho juga mengoptimalkan fungsi intermediasi BMT sehingga bisa menjembatani kepentingan beberapa kelompok masyarakat untuk bersinergi.

${ }^{7}$ Nurul Huda dan Muhammad Heykal, Lembaga Kenangan Islam: Tinjanan Teoritis dan Praktis (Jakarta: Kencana Prenada Media Group, 2010), 363-364.

${ }^{8}$ Sumber: Neraca BMT Ar-Ridho per 30 Nopember 2014.

${ }^{9}$ Sumber: Dokumen BMT Ar-Ridho Trenggalek 2014. 


\section{Orientasi Pemberdayaan Ekonomi Masyarakat}

Menurut Korten, pemberdayaan adalah peningkatan kemandirian rakyat berdasarkan kapasitas dan kekuatan internal rakyat atas sumber daya manusia, baik material maupun non-material melalui redistribusi modal. ${ }^{10}$ Pranarka dan Vidhyandika menjelaskan bahwa pemberdayaan adalah upaya mewujudkan suasana kemanusiaan yang adil dan beradab menjadi semakin efektif secara struktural, baik di dalam kehidupan keluarga, masyarakat, negara, regional, internasional, maupun dalam bidang politik, ekonomi, dan lain sebagainya. ${ }^{11}$ Sementara itu Samuel Paul mengartikan pemberdayaan sebagai pembagian kekuasaan yang adil (equitable sharing of power) sehingga meningkatkan kesadaran politis dan kekuasaan kelompok yang lemah serta memerbesar pengaruh mereka terhadap proses dan hasil-hasil pembangunan. ${ }^{12}$ Sedangkan menurut Robert Dahl, pemberdayaan adalah pemberian kuasa untuk memengaruhi atau mengontrol. ${ }^{13}$ Jadi pemberdayaan setidaknya mengandung empat unsur, antara lain: kesadaran untuk berubah, kemandirian ekonomi maupun nonekonomi, terwujudnya tata sosial yang beradab dan adanya kemampuan untuk melakukan kontrol.

Prinsip utama pemberdayaan masyarakat menurut Drijver dan Sajise ada lima, yaitu: ${ }^{14}$

a. Pendekatan dari bawah (buttom up approach). Pada kondisi ini para stakeholder setuju pada tujuan yang ingin dicapai dengan cara mengembangkan gagasan dan beberapa kegiatan bertahap.

\footnotetext{
${ }^{10}$ David C. Korten, People Centered Development: Reflections on Development Theory and Methods (Manila: ADB, 1992), 14.

11 A.M.W. Pranarka dan Vidhyandika Moeljarto, Pemberdayaan: Konsep, Kebijakan, dan Implementasi (Jakarta: CSIS, 1996), 56.

12 Samuel Paul, "Community Participation in Development Projects-The World Bank Experience", dalam M. Bamberger (compiler), Readings in Community Participation, Vol. 1 (The Economic Development Institute of the World Bank, Washington, DC, 1986), 46.

13 Robert Dahl, Democracy and Its Critics (New Haven Conn: Yale University Press, 1983), 50.

${ }^{14}$ C. Drijver, dan P. Sajise, Community-Based Resource Management and Environmental Action Research, dalam Proceedings of the Experts' Workshop on Community Based Resource Management: Perspectives, Experiences and Policy Issues, Los Banos, Philippines (UPLB), Environmental and Resource Management Project \& UPLB., 1993. Silahkan dibaca pula dalam Sutrisno, Menuju Masyarakat Partisipatif (Yogyakarta: Penerbit Kanisius, 2005), 18.
} 
b. Partisipasi (participation), di mana setiap aktor yang terlibat memiliki kekuasaan dalam setiap fase perencanaan dan pengelolaan.

c. Konsep keberlanjutan, yaitu pengembangan kemitraan dengan seluruh lapisan masyarakat sehingga program pembangunan berkelanjutan dapat diterima secara sosial dan ekonomi.

d. Keterpaduan kebijakan dan strategi tingkat lokal, regional dan nasional.

e. Keuntungan sosial dan ekonomi.

Maksud dilakukannya pemberdayaan adalah untuk terwujudnya perubahan, baik individu maupun kelompok melalui proses tertentu. Hal ini sesuai dengan pendapat Hulme dan Turner yang menyatakan bahwa pemberdayaan mendorong terjadinya suatu proses perubahan sosial yang memungkinkan orang-orang pinggiran yang tidak berdaya untuk memberikan pengaruh yang lebih besar di arena politik secara lokal maupun nasional. ${ }^{15}$ Demikian juga Kieffer berpendapat bahwa pemberdayaan memiliki tiga dimensi yang saling berpotongan dan bersinggungan, yaitu: perkembangan konsep diri yang lebih positif, kondisi pemahaman yang lebih kritis dan analitis mengenai lingkungan sosial dan politis, dan adanya sumber daya individu dan kelompok untuk aksi-aksi sosial maupun kelompok. ${ }^{16}$

Proses pemberdayaan masyarakat dapat dilakukan secara individual maupun kolektif atau menuju kolektivitas. Menurut Friedmann, proses pemberdayaan merupakan wujud perubahan sosial yang menyangkut relasi antara lapisan sosial yang dicirikan dengan adanya polarisasi ekonomi, maka kemampuan individu "senasib" untuk saling berkumpul dalam suatu kelompok cenderung dinilai sebagai bentuk pemberdayaan yang paling efektif. ${ }^{17}$

Strategi pemberdayaan menurut Jim Ife yakni: a) pemberdayaan melalui perencanaan dan kebijakan (policy and planning), b) pemberdayaan melalui aksi sosial dan politik (social and political action),

15 David Hulme dan M. Turner, Sociology of Development: Theories, Policies, and Practices (Hertfordshire: Harvester Whearsheaf, 1990), 214-215.

${ }^{16}$ Kieffer, C. H., Citizen Empowerment: A Developmental Perspective, Prevention in Human Service, Vol. 3, USA (1984), 65.

17 Pendekatan yang digunakan oleh Friedmann sebenarnya pendekatan keluarga. Friedmann memiliki pandangan bahwa setiap rumah tangga memiliki tiga macam kekuatan, yaitu kekuatan sosial, kekuatan politik, dan kekuatan psikologis. Pandangan Friedmann ini kemudian menghasilkan rumusan mengenai pemberdayaan sebagai proses untuk masyarakat lemah memeroleh kekuatan dan akses terhadap sumberdaya. Baca John Friedmann, Empowerment: the Politics of Alternative Development (Cambridge Mass: Blackwell Publisher, 1992). 
dan c) pemberdayaan melalui peningkatan kesadaran dan pendidikan (education and consciousness raising). ${ }^{18} \mathrm{Jadi}$ pemberdayaan harus memihak kepada kelompok kurang beruntung serta dilakukan perencanaan yang matang melalui aksi nyata yang ditunjang dengan peningkatan kesadaran.

Menurut Ginanjar Kartasasmita, upaya memberdayakan masyarakat harus dilakukan melalui tiga cara, yaitu:

a. Menciptakan suasana yang memungkinkan potensi masyarakat untuk berkembang.

b. Memerkuat potensi yang dimiliki oleh rakyat dengan menampung berbagai masukan, menyediakan sarana dan prasarana.

c. Melindungi dan membela kepentingan masyarakat lemah. ${ }^{19}$

Sedangkan Kurt Lewin ${ }^{20}$ mengenalkan konsep pemberdayaan dengan model force-field yang diklasifikasi sebagai model power-based karena menekankan kekuatan-kekuatan penekanan. Menurutnya, perubahan terjadi karena munculnya tekanan-tekanan terhadap organisasi, individu, atau kelompok. Lewin berkesimpulan bahwa kekuatan tekanan (driving force) akan berhadapan dengan penolakan (resistences) untuk berubah. ${ }^{21}$

Berdasarkan pendapat para ahli pemberdayaan tersebut, maka dapat disimpulkan bahwa teknik pemberdayaan tidak boleh top down, namun harus bottom up. Selain itu harus ada perencanaan yang matang, pemantauan dan pengembangan yang berkelanjutan. Sedangkan pola pendekatan pemberdayaan yang tepat adalah memberi peluang yang besar bagi masyarakat untuk berdaya serta melatih mereka untuk berdaya berdasarkan inisiatif dari mereka. Sekalipun demikian,

18 Jim Ife, Community Development: Creating Community Alternatives-Vision, Analysis and Practice (Australia: Longmann, 1995), 63.

19 Ginanjar Kartasasmita, Pembangunan untuk Rakyat (Jakarta: Pustaka Gramedia, 1995), 19.

${ }^{20}$ Kurt Lewin, Field Theory in Social Science: Selected Theoretical Papers, D. Cartwright (ed.). (New York: Harper dan Row, 1951). Penjelasan tentang force-field selengkapnya juga bisa dibaca dalam V.G. Kondalkar, Organizational Behaviour (New Delhi: New Age International Publisers, 2007), 297-298.

21 Secara paradoks, pemberdayaan seringkali merusak pembangunan demokrasi kekuasaan yang terseirat oleh konseptualisasi pemberdayaan. Pendapat seperti ini misalnya disampaikan oleh Gruber dan Trickett, 1987: Kizilos, 1990: Simon, 1990. Lihat Simon, B.L., "Rethinking Empowerment, Journal of Progressive Human Services, Vol. 1(1) (1990), 27-39. Lihat juga J. Gruber dan E.J. Trickett, "Can We Empower Others? The Paradox of Empowerment in the Governing of an Alternative Public School”, American Journal of Community Psychology, Vol. 15(3) (1987), 353-371. 
ketersediaan suasana dan saran pemberdayaan menjadi hal yang penting. Selain itu harus dipastikan bahwa masyarakat terhindar dari eksploitasi dan mereka memeroleh kesempatan yang sama di dalam berusaha.

Dalam al-Qur'ân kata daya disebut sebagai al-qumwah, dan di dalam berbagai variannya disebut sebanyak 33 kali. ${ }^{22}$ Secara normatif, perubahan menuju keberdayaan diperintahkan oleh Allah, seperti dalam Q.S. al-Ra'd [13]: 11 disebutkan:

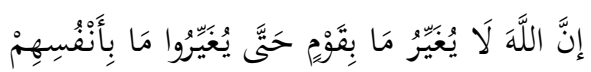

"Sesungguhnya Allah tidak akan mengubah keadaan suatu kaum hingga mereka mengubah keadaan yang ada pada diri mereka sendiri" 23

Menurut al-Bayḍ̂âî, lafal mâ dalam ayat di atas dimaknai sikap yang dikaitkan dengan kenikmatan yang telah diberikan oleh Allah. ${ }^{24}$

Sifat pemberdayaan bukanlah sesaat atau berhenti pada satu program saja, namun harus tetap berkelanjutan. Bahkan pemberdayaan harus dilakukan dengan memerhitungkan hingga generasi berikutnya. Islam memerintahkan kepada kita untuk meninggalkan generasi penerus dalam keadaan berdaya. Allah menyampaikan dalam Q.S. al-Nisâ' [4]: 9 yang artinya:

“...dan hendaklah takut kepada Allah orang-orang yang seandainya meninggalkan dibelakang mereka anak-anak yang lemah, yang mereka khawatir terhadap (kesejahteraan) mereka. Oleh sebab itu hendaklah mereka bertakwa kepada Allah dan hendaklah mereka mengucapkan perkataan yang benar". ${ }^{25}$

Tantâwî Jawharî berpendapat bahwa ayat di atas ditujukan kepada semua pihak, karena semua diperintahkan untuk berlaku adil, berucap yang benar karena kekhawatiran akan mengalami keadaan seperti yang digambarkan ayat di atas. ${ }^{26}$ Ayat tersebut menunjukkan bahwa Allah tidak menyukai orang-orang yang meninggalkan generasi dalam

22 Lihat Fu'âd 'Abd al-Bâqî, Mu'jam al-Mufahras li Alfâz̆ al-Qur'ân al-Karîm (Beirut: Dâr al-Fikr, 1981), 587-588.

23 al-Qur'ân, 13: 11.

${ }^{24}$ Selengkapnya dapat dibaca dalam, Nâșir al-Dîn Abû Sa'îd 'Abd Allâh b. 'Umar b. Muḥammad al-Shîrâzî al-Bayḍ̂ûî, Anwâr al-Tanzîl wa Asrâr al-Ta'wîl, Vol. 3. Beirut: Muassasah Sha'bân, t.th.), 148.

25 al-Qur'ân, 4: 9.

26 Tanțâwî Jawharî, al-Jawâhir fî Tafsîr al-Qur'ân al-Karîm (Damaskus: Dâr al-Fikr, t.th.). 
keadaan lemah. Mafbûm mukhâlafah-nya bahwa Allah mencintai orangorang yang meninggalkan generasi sesudahnya dalam keadaan kuat atau berdaya. Hal ini diperkuat dengan hadîth Nabi:

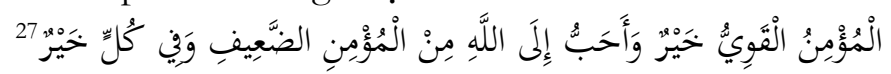

"Mukmin yang kuat lebih baik dan lebih dicintai Allah daripada mukmin yang lemah dan pada masing-masing terdapat kebaikan”.

Bentuk utama pemberdayaan yang dilakukan oleh BMT adalah menyelenggarakan pembiayaan-pembiayaan. Pembiayaan untuk usaha kerjasama dengan prinsip bagi hasil yang meliputi mushârakah dan mudârabah yang semestinya bisa dikembangkan secara maksimal karena produk ini merupakan core dari lembaga keuangan sharî‘ ah, termasuk BMT. Dewan Sharî́ah Nasional MUI dalam salah satu fatwanya yaitu fatwa nomor 14 tentang sistem distribusi hasil usaha dalam LKS menyebutkan bahwa saat ini jika dilihat dari segi kemaslahatan, maka pembagian usaha sebaiknya dilakukan dalam prinsip bagi hasil (net revenue sharing). ${ }^{28}$ Secara normatif Allah juga memerintahkan kerjasama mushârakah dan mudârabah seperti dalam Q.S. al-Mâidah [5]: 2 yang artinya:

"Dan tolong-menolonglah kamu dalam (mengerjakan) kebajikan dan takwa, dan jangan tolong-menolong dalam berbuat dosa dan pelanggaran. Dan bertakwalah kamu kepada Allah, sesungguhnya Allah amat berat siksa-Nya". ${ }^{29}$

Dewan Syariah Nasional MUI menggunakan ayat tersebut sebagai salah satu rujukan dalam memutuskan beberapa fatwa yang berkaitan dengan pembiayaan. Misalnya fatwa nomor 7 tentang mudârabah, fatwa nomor 8 tentang mushârakah, fatwa nomor 29 tentang

\footnotetext{
${ }^{27}$ Hadith tersebut diriwayatkan oleh Muslim di dalam Kitab al-Qadar, bab. Imân li alQadar wa al-Idb`ân lah.

${ }^{28}$ Fatwa DSN No: 15/DSN-MUI/IX/2000 tentang Prinsip Distribusi Hasil Usaha dalam LKS.

${ }^{29}$ Departemen Agama RI, Al-Qur'ân dan Terjemahannya, 5: 2. Sekalipun ayat tersebut tidak dikhususkan untuk persoalan tolong menolong dalam bisnis atau asbâb alnu₹ulnya juga tidak berkaitan dengan bisnis, namun keumuman sebuah ayat dapat dipakai sebagai dalil dalam menghukumi atau menguatkan sebuah argumentasi. Dalam kaitannya dengan hal ini terdapat satu kaidah usul fiqh yang menyatakan bahwa pelajaran itu diambil dari umumnya lafal dan bukan dari khususnya sebab al‘brah bi 'umûm al-laf: lâ bi khusûs.s al-sabab. Muhammad b. 'Alî b. Muhammad b. 'Abd Allâh al-Shawkânî al-Yamanî, Fatḥ al-Qadîr, Vol. 5 (Damaskus: Dâr Ibn Kathîr, 1994), 246.
} 
pembiayaan pengurusan haji, fatwa nomor 53 tentang akad tabarru' pada asuransi sharî́ah dan sebagainya.

\section{Fungsi Intermediasi dan Pembiayaan BMT}

Makhalul Ilmi membedakan antara bayt al mâl dan bayt tamwîl. Bayt al mâl adalah lembaga keuangan berorientasi sosial keagamaan yang kegiatan utamanya menampung serta menyalurkan harta masyarakat berupa zakat, infaq dan șadaqah berdasarkan ketentuan yang ditetapkan al-Quran dan Sunnah. Sedangkan bayt tamwîl adalah lembaga keuangan yang kegiatan utamanya menghimpun dana masyarakat dalam bentuk tabungan (simpanan) maupun deposito dan menyalurkannya kembali kepada masyarakat dalam bentuk pembiayaan berdasarkan prinsip sharî‘ ah melalui mekanisme yang lazim dalam dunia perbankan. ${ }^{30}$

Menurut Pusat Inkubasi Bisnis Usaha Kecil, tujuan BMT antara lain: a). Meningkatkan kualitas usaha ekonomi untuk kesejahteraan anggota pada khususnya dan masyarakat pada umumnya, b). Mewujudkan gerakan pembebasan anggota dari rentenir, jerat kemiskinan dan ekonomi ribawi. c). Mewujudkan gerakan pemberdayaan meningkatkan kapasitas dalam kegiatan ekonomi riil dan kelembagaannya menuju tatanan perekonomian yang makmur dan maju, serta d). Mewujudkan gerakan keadilan membangun struktur masyarakat madani yang adil berkemakmuran, berkemajuan, serta berkeadilan berlandaskan sharî‘ ah dan ridha Allah. ${ }^{31}$

Dengan demikian fungsi BMT tidak sekedar sebagai intermediasi ekonomi, namun juga sebagai intermediasi sosial di masyarakat. Dua fungsi intermediasi ini tidak dapat dilepaskan satu dengan yang lainnya namun menyatu dalam aktivitas BMT. BMT lebih bersifat terbuka dan mengedepankan kesejahteraan anggota dan masyarakat seperti disampaikan Ahmad bahwa sifat BMT adalah terbuka, independen, tidak partisan, berorientasi pada pengembangan simpanan dan pembiayaan, sangat mendukung bisnis ekonomi yang produktif bagi anggota dan kesejahteraan sosial masyarakat sekitar. ${ }^{32}$

\footnotetext{
${ }^{30}$ Makhalul Ilmi SM, Teori dan Praktek Lembaga Mikro Kenangan Syariah (Yogyakarta: UII Press, 2002), 65-67.

31 Pusat Inkubasi Bisnis Usaha Kecil, BMT sebagai Alternatif Model Lembaga Kenangan Mikro: LKM (Jakarta: Pusat Inkubasi Bisnis Usaha Kecil, t.th.). 9-10.

32 Ahmad Sumiyanto, BMT Menuju Koperasi Modern (Solo: ISES Publishing, 2008), 174.
} 
Fungsi intermediasi BMT dijelaskan lebih kongkret oleh Huda dan Heykal bahwa peran BMT adalah sebagai berikut: a) Sebagai motor penggerak ekonomi dan sosial masyarakat banyak, b) Ujung tombak pelaksanaan sistem ekonomi sharî‘ah, c) Penghubung antara kaum aghniyâ (kaya) dan kaum du'afâ' (miskin)., dan d) Sarana pendidikan informal untuk mewujudkan prinsip hidup yang barakah, ạ̣san 'amala, dan salâm melalui spiritual communication dengan dhiker qalbîyah ilâhîyah. ${ }^{33}$ Dengan demikian fungsi dan peran BMT sangat strategis dalam rangka menunjang pemberdayaan masyarakat secara ekonomi, sosial maupun religius.

Sedangkan pembiayaan memiliki urgensitas dalam aktivitas BMT terutama sebagai alat untuk membantu kelancaran usaha nasabah sehingga diharapkan lebih berdaya. Selain itu pembiayaan akan menghasilkan keuntungan bagi BMT itu sendiri dan secara otomatis akan menunjang upaya pemerintah untuk menciptakan kesejahteraan masyarakat. Oleh karena itu semakin besar jumlah pembiayaan serta semakin cepat perputaran uang untuk pembiayaan maka semakin baik akses yang ditimbulkannya. Menurut Adiwarman Karim, produk pembiayaan sharî́ah terbagi ke dalam empat kategori yang dibedakan berdasarkan tujuan dan sistem transaksinya, yaitu: a). Pembiayaan dengan prinsip jual-beli, b). Pembiayaan dengan prinsip sewa, c). Pembiayaan dengan prinsip bagi hasil, dan d). Pembiayaan dengan akad pelengkap. ${ }^{34}$

\section{Profil dan Kinerja BMT Ar-Ridho}

BMT Ar-Ridho berlokasi di Desa Gondang RT 1 RW 1 Kecamatan Tugu Kabupaten Trenggalek, beroperasi sejak tahun 1998 dan mulai mendapatkan ijin operasi pada tahun 1999 di bawah payung hukum nomor: 12/BH/KDK.13-20/1.1/II/1999 tanggal 15 Februari 1999.

Pemrakarsa BMT Ar-Ridho antara lain Imam Supandi, Thohari, Cholil Madjid, dan Khoiri. Dari prakarsa empat orang tersebut, selanjutnya dikumpulkan tokoh-tokoh agama yang ada di kecamatan Tugu-Trenggalek sejumlah 31 (tiga puluh satu) tokoh. Para tokoh agama tersebut kemudian merupakan pendiri awal dari BMT ArRidho, yaitu: Imam Supandi, Thohari, Imam Khairi, Kusdam, Nandayani, Parlan, Imam Mawardi, Haryono, Nurhadi, Haryati,

\footnotetext{
${ }^{33}$ Huda dan Heykal, Lembaga Kenangan Islam, 365.

${ }^{34}$ Adiwarman Karim, Bank Islam Analisis Fiqih dan Kenangan (Jakarta: RajaGrafindo, 2004), 8.
} 
Suyatmo. Cholil Madjid, Rudi Susanto, Kusnan, Ny. Slamet Riadi, Ismail, Ahmad Dahlan, A Sanusi, Gunawan, Marsi, Suparni, Srtono, Ranu, Suyono, Wasis, Sukaryo, Susara, Kurniyati, Sudarti, dan Ika Erlinawati.

Hingga akhir bulan September 2014, aset yang dimiliki BMT ArRidho sebesar Rp 10.542.423.820, $-^{35}$ dengan jumlah nasabah 4.918 orang. Dari total aset yang dimilki oleh BMT Ar Ridho tersebut, 95\% nya dialokasikan untuk pembiayaan. Sedangkan jumlah nasabah yang masih aktif dalam pembiayaan adalah 3.170 orang. Selengkapnya berkaitan dengan profil, produk dan kinerja BMT Ar-Ridho dapat dilihat dalam tabel berikut.

Tabel 1. Profil BMT Ar-Ridho

\begin{tabular}{|c|c|}
\hline Nama & BMT Ar-Ridho \\
\hline Alamat & RT 1 RW 1 Gondang Tugu Trenggalek \\
\hline Tahun berdiri & 1998 \\
\hline Badan Hukum & $\begin{array}{l}\text { Nomor: } 12 / \mathrm{BH} / \mathrm{KDK} .13-20 / 1.1 / \mathrm{II} / 1999 \\
\text { tanggal } 15 \text { Februari } 1999\end{array}$ \\
\hline Visi & $\begin{array}{l}\text { Unggul dalam pelayanan, mudah dan cepat } \\
\text { berdasarkan sharî'ah demi pemberdayaan } \\
\text { ekonomi kerakyatan }\end{array}$ \\
\hline Misi & $\begin{array}{l}\text { 1. Penunjang kegiatan ekonomi } \\
\text { masyarakat kecil berdasarkan sistem } \\
\text { sharî'ah } \\
\text { 2. Menyediakan sarana keuangan sharî'ah } \\
\text { yang mudah dijangkau masyarakat } \\
\text { 3. Menjadi wahana menabung yang } \\
\text { menguntungkan. } \\
\text { 4. Menjadi lembaga keuangan sharî'ah } \\
\text { yang menjembatani aghniyâ' dan du'afâ' } \\
\text { 5. Menyediakan sarana permodalan yang } \\
\text { falâh } \\
\text { 6. Mengangkat kehidupan para du'afâ' } \\
\text { secara terpola dan berkesinambungan }\end{array}$ \\
\hline Dewan Pendiri & 31 orang \\
\hline Dewan Pengurus & 11 orang \\
\hline Produk & suka rela, tabungan \\
\hline
\end{tabular}

35 Jumlah aset ini terus bertambah pada saat penelitian ini dilakukan. Progresivitas aset ini dapat dilihat dengan perbandingan aset pada tahun 2012 sebesar Rp 9.154.056.120,-. Dalam rentang waktu dua tahun saja, BMT Ar-Ridho telah mampu menambah asetnya di atas 1,5 miliar rupiah. 


\begin{tabular}{|c|c|}
\hline & $\begin{array}{l}\text { persiapan qurban, tabungan pendidikan, } \\
\text { tabungan persiapan nikah, tabungan } \\
\text { persiapan melahirkan, tabungan naik } \\
\text { haji/umroh, simpanan berjangka/deposito, } \\
\text { simpanan khusus untuk kelahiran, } \\
\text { simpanan sukarela, simpanan hari tua, dan } \\
\text { simpanan 'aqiqah. } \\
\text { Lending: Pembiayaan modal kerja, } \\
\text { pembiayaan usaha, pembiayaan } \\
\text { perdagangan, pembiayaan pertanian, dan } \\
\text { pembiayaan kebutuhan sehari-hari }\end{array}$ \\
\hline Aset & Rp 10.542.423.820,- \\
\hline Terserap Pembiayaan & Rp 9.943.495.850,- \\
\hline Jumlah Nasabah & 4.918 orang \\
\hline $\begin{array}{l}\text { Nasabah Aktif } \\
\text { Pembiayaan }\end{array}$ & 3.170 orang \\
\hline
\end{tabular}

Sumber: Peneliti, diolah dari dokumentasi dan hasil wawancara pada pengelola BMT, 2014.

Tahun 2009, Deputi Bidang Kelembagaan Koperasi dan UKM Kementrian Negara Koperasi dan UKM memberikan penghargaan kepada BMT Ar-Ridho berupa sertifikat peringkat koperasi dengan status "cukup berkualitas". Tahun 2010, BMT Ar-Ridho mendapat penghargaan dari Gubernur Jawa Timur sebagai KJKS terbaik ke-II di Jawa Timur. Pada tahun 2013, BMT Ar-Ridho mendapat penghargaan dari Kepala Dinas Koperasi, Industri, Perdagangan, Pertambangan dan Energi Kabupaten Trenggalek sebagai juara I koperasi berprestasi se-Kabupaten Trenggalek.

Sejak tahun 1998, BMT Ar-Ridho mendata kaum miskin di sekitar BMT untuk diajak dialog agar diketahui keterbatasan-keterbatasan mereka, misalnya kemampuan bisnis, modal, skill atau jaringan. Terhadap kelompok miskin dan terpinggirkan tersebut dilakukan treatment berupa pemberian motivasi. Pendekatan kepada kaum miskin dan terpinggirkan ini juga dilakukan dengan program-program rutin berupa santunan, sunatan masal, atau pembagian daging kurban. ${ }^{36}$

\footnotetext{
36 Ika Erlinawati, Wawancara, Trenggalek, 12 Desember 2014. Kegiatan sosial tersebut bukan diniatkan untuk sekedar menyenangkan masyarakat, namun merupakan strategi agar mampu memberdayakan masyarakat. Memang Sohrab Behdad pernah mengatakan bahwa ekonomi Islam lebih bersifat elektis karena berusaha menyenangkan segala masyarakat untuk orientasinya yang bersifat popolis. Baca Sohrab Behdad, "Property Rights in Contemporary Islamic Economic
} 
Kegiatan sosial yang dilakukan oleh BMT Ar-Ridho dari tahun ke tahun mengalami peningkatan seperti tertera dalam tabel berikut.

Tabel 2.

\begin{tabular}{|c|c|c|c|c|c|c|}
\hline \multicolumn{7}{|c|}{ Pendekatan dan Kegiatan Sosial BMT Ar-Ridho } \\
\hline Kegiatan & $1998-$ & 2010 & 2011 & 2012 & 2013 & 2014 \\
\hline & 2009 & & & & & \\
\hline Santunan & $1-50$ & $36 / \mathrm{bln}$ & $45 / \mathrm{bln}$ & $56 /$ bln & $56 /$ bln & $70 / \mathrm{bln}$ \\
\hline yatim & orang & & & & & \\
\hline Beasiswa & - & - & - & 20 anak & 20 anak & 27 \\
\hline & & & & & & anak \\
\hline Sunatan & 15 & - & 15 anak & 15 anak & 14 anak & 15 \\
\hline Masal & anak & & & & & anak \\
\hline $\begin{array}{l}\text { Tebar } \\
\text { daging }\end{array}$ & $\begin{array}{l}200 \\
\mathrm{rmh}\end{array}$ & $\begin{array}{l}400 \\
\mathrm{rmh}\end{array}$ & $\begin{array}{l}400 \\
\mathrm{rmh}\end{array}$ & $\begin{array}{l}400 \\
\mathrm{rmh}\end{array}$ & $450 \mathrm{rmh}$ & $\begin{array}{l}450 \\
\mathrm{rmh}\end{array}$ \\
\hline kurban & & & & & & \\
\hline
\end{tabular}

Sumber: Dokumen BMT Ar-Ridho yang telah diolah peneliti, 2014.

Tahun 2010 hingga tahun 2014 telah muncul 5 jasa fotocopy, 7 peternak domba dengan kapasitas 100 hingga 150 ekor, 2 pabrik home industy tepung kasafa, dan 5 toko baju. Semua merupakan nasabah binaan BMT Ar-Ridho. ${ }^{37}$ Bahkan sebagian besar penabung di BMT Ar-Ridho saat ini adalah mereka yang dahulu mendapat pembiayaan. ${ }^{38}$ Hingga saat ini terdapat lebih dari 20 nasabah yang membangun bisnisnya dengan kerjasama dengan nasabah lainnya. ${ }^{39}$ Dengan demikian pembiayaan disertai pembinaan nasabah oleh BMT ArRidho menjadikan kondisi nasabah lebih berkembang.

Dari tahun 1998 hingga 2014, fungsi intermediasi ekonomi yang dijalankan oleh BMT Ar-Ridho terangkum sebagai berikut.

\section{Tabel 3.}

Intermediasi Dana oleh BMT Ar-Ridho 2011 s/d 2014

\begin{tabular}{|c|c|c|}
\hline Tahun & Tabungan/Investasi & Pembiayaan \\
\hline 2011 & Rp 4.358.241.400,- & Rp 4.179.338.000,- \\
\hline 2012 & Rp 9.089.794.700,-- & $\operatorname{Rp~8.243.966.350,-~}$ \\
\hline 2013 & Rp 9.154.056.120,- & $R p 8.104 .261 .760,-$ \\
\hline
\end{tabular}

\footnotetext{
Thought: A Critical Perspective", Review of Social Economy, Summer, Vol. 47, No. 2 (1999), 185.

${ }^{37}$ Hardina, W awancara, Trenggalek, 12 Desember 2014.

${ }^{38}$ Hardina Saputra, Wawancara, Trenggalek, 18 Desember 2014.

${ }^{39}$ Hardina, Wawancara, Trenggalek, 12 Desember 2014.
} 
\begin{tabular}{l|l|l}
2014 & Rp 9.943.495.850,- & Rp 10.542.423.820,-
\end{tabular}

Sumber: Data BMT Ar-Ridho yang dimodifikasi oleh peneliti, 2014.

Dalam hal pembiayaan, dana yang dikeluarkan pada tahun 2011 untuk pembiayaan produktif sekitar Rp 1.780.000.000,-. Tahun 2012 meningkat menjadi Rp 2.149.000.000,- dan tahun 2013 meningkat menjadi Rp 2.310.000.000,-. Pada tahun 2014 meningkat menjadi Rp 3.531.370.000,-. Pada tahun 2011 terdapat 967 orang yang dibiayai dengan skema mudârabah dan 21 orang dibiayai dengan skema mushârakah. Pada tahun 2012 meningkat menjadi menjadi 1.430 orang yang dibiayai dengan skema mudârabah dan terdapat 31 orang yang dibiayai dengan skema mushârakah. Pada tahun 2013 meningkat menjadi 1.451 orang yang dibiayai dengan skema mudârabah dan terdapat 34 orang yang dibiayai dengan skema mushârakah. Pada tahun 2014 terdapat 2.998 oarang yang dibiayai dengan skema mudârabah dan terdapat 36 orang yang dibiayai dengan skema mushârakah.

Untuk pembiayaan investasi, pada tahun 2011 dana yang dikeluarkan sebesar Rp 982.500.000,-. Pada tahun 2012 meningkat menjadi Rp 1.152.000.000,-. Pada tahun 2013 meningkat menjadi Rp 1.220.000.000,-. Sedangkan pada tahun 2014 meningkat menjadi Rp 1.321.000.000,-. Sementara itu dari sisi jumlah nasabah juga terdapat peningkatan. Pada tahun 2011 terdapat 61 orang yang dibiayai dalam pembiayaan investasi. Pada tahun 2012 meningkat menjadi 80 orang. Pada tahun 2013 meningkat menjadi 91 orang. Selanjutnya pada tahun 2014 meningkat lagi menjadi 94 orang.

Sementara pembiayaan konsumtif di BMT Ar-Ridho cenderung stabil bahkan tidak mengalami peningkatan. Salah satu penyebabnya adalah karena pihak managemen BMT Ar-Ridho banyak memotivasi masyarakat dan nasabah untuk melakukan pembiayaan produktif. Pada tahun 2011 dana yang dikeluarkan untuk pembiayaan konsumtif sebesar Rp 3.766.800.000,-. Pada tahun 2012 meningkat menjadi Rp 5.152.000.000,-. Selanjutnya pada tahun 2013 turun menjadi Rp 4.220.000.000,-. Sedangkan pada tahun 2014 meningkat lagi menjadi Rp 5.321.000.000,-.pembiayaan konsumtif ini lebih fluktuatif dibandingkan dengan jenis pembiayaan lainnya. Dari sisi jumlah nasabah pembiayaan konsumtif juga relatif tidak stabil. Pada tahun 2011 terdapat 65 orang dan pada tahun 2012 terdapat 90 orang dan pada tahun 2013 meningkat menjadi 93 orang. Selanjutnya pada tahun 2014 turun menjadi 84 orang. 
Pembiayaan jasa ditetapkan dengan akad ijârah muntahiya bi tamlik. Pada tahun 2011 dana yang dikeluarkan untuk pembiayaan jasa sebesar Rp 711.120.000,-. Pada tahun 2012 meningkat menjadi Rp 852.400.000,-. Pada tahun 2013 meningkat menjadi Rp 820.500.000,-Sedangkan pada tahun 2014 meningkat lagi menjadi Rp 1.111.000.000,-. Pada tahun 2011 terdapat 11 orang dan pada tahun 2012 terdapat 32 orang. Selanjutnya pada tahun 2013 meningkat menjadi 33 orang. Selanjutnya pada tahun 2014 menjadi 44 orang.

\section{Keterpaduan Fungsi Intermediasi, Pembiayaan dan Pemberdayaan Ekonomi Masyarakat}

BMT Ar-Ridho melakukan stepping pemberdayaan sebagai berikut: interaksi intensif dengan masyarakat, penanaman kesadaran atau kesamaan pikiran, pembentukan kelompok-kelompok terkoordinir, pembinaan nasabah secara intensif, partisipasi aktif, dan pelaku aktif dalam upaya keberlanjutan pemberdayaan.

Setiap stepping memiliki standar dengan menggunakan alat uji yang berbeda-beda seperti dalam tabel berikut ini.

Tabel 4.

\begin{tabular}{|c|l|l|l|}
\hline \multicolumn{4}{|c|}{ Standar keberhasilan stepping pemberdayaan } \\
\hline No & \multicolumn{1}{|c|}{ Stepping } & \multicolumn{1}{|c|}{$\begin{array}{c}\text { Standar } \\
\text { keberhasilan }\end{array}$} & \multicolumn{1}{c|}{ Alat Uji } \\
\hline 1 & $\begin{array}{l}\text { Interaksi intensif } \\
\text { dengan masyarakat }\end{array}$ & $\begin{array}{l}\text { Masyarakat prablem } \\
\text { memahami proban } \\
\text { dan kemungkinan } \\
\text { solusinya }\end{array}$ & $\begin{array}{l}\text { Pertanyaan } \\
\text { wawancara dan } \\
\text { diskusi }\end{array}$ \\
\hline 2 & $\begin{array}{l}\text { Penanaman } \\
\text { kesadaran }\end{array}$ & $\begin{array}{l}\text { Bergabung dengan } \\
\text { BMT }\end{array}$ & $\begin{array}{l}\text { Formulir } \\
\text { keanggotan BMT }\end{array}$ \\
\hline 3 & $\begin{array}{l}\text { Pembentukan } \\
\text { kelompok binaan }\end{array}$ & $\begin{array}{l}\text { Terdapat struktur } \\
\text { organisasi kelompok } \\
\text { binaan }\end{array}$ & $\begin{array}{l}\text { Susunan pengurus } \\
\text { kelompok }\end{array}$ \\
\hline 4 & Pembinaan intensif & $\begin{array}{l}\text { Dihadiri oleh } \\
\text { sebagian besar } \\
\text { anggota tiap kali ada } \\
\text { kegiatan pembinaan }\end{array}$ & $\begin{array}{l}\text { Absensi, evaluasi, } \\
\text { checklist } \\
\text { perkembangan } \\
\text { usaha }\end{array}$ \\
\hline 5 & Partisipasi aktif & $\begin{array}{l}\text { Pelunasan pembiayan } \\
\text { dan peningkatan } \\
\text { tabungan dari waktu } \\
\text { ke waktu }\end{array}$ & Buku tabungan \\
\hline 6 & Keberlanjutan & Terwujudnya investasi & Akad-akad funding \\
\hline
\end{tabular}




\begin{tabular}{|l|l|l|l|}
\hline pemberdayaan & $\begin{array}{l}\text { dan membayar zakat, } \\
\text { infaq dan sadaqah }\end{array}$ & \\
\hline
\end{tabular}

Sumber: modifikasi peneliti, 2014.

Stepping pemberdayaan tersebut dilakukan oleh sumber daya insani yang memiliki visi dan misi pemberdayaan serta kepatuhan pada prinsip sharî́ah dan ditunjang oleh regulasi pemerintah, lembagalembaga profesi dan inkubasi, serta para nasabah. Sehingga keterkaitan BMT dengan pihak-pihak lain dalam kerangka stepping pemberdayaan dapat digambarkan sebagai berikut.

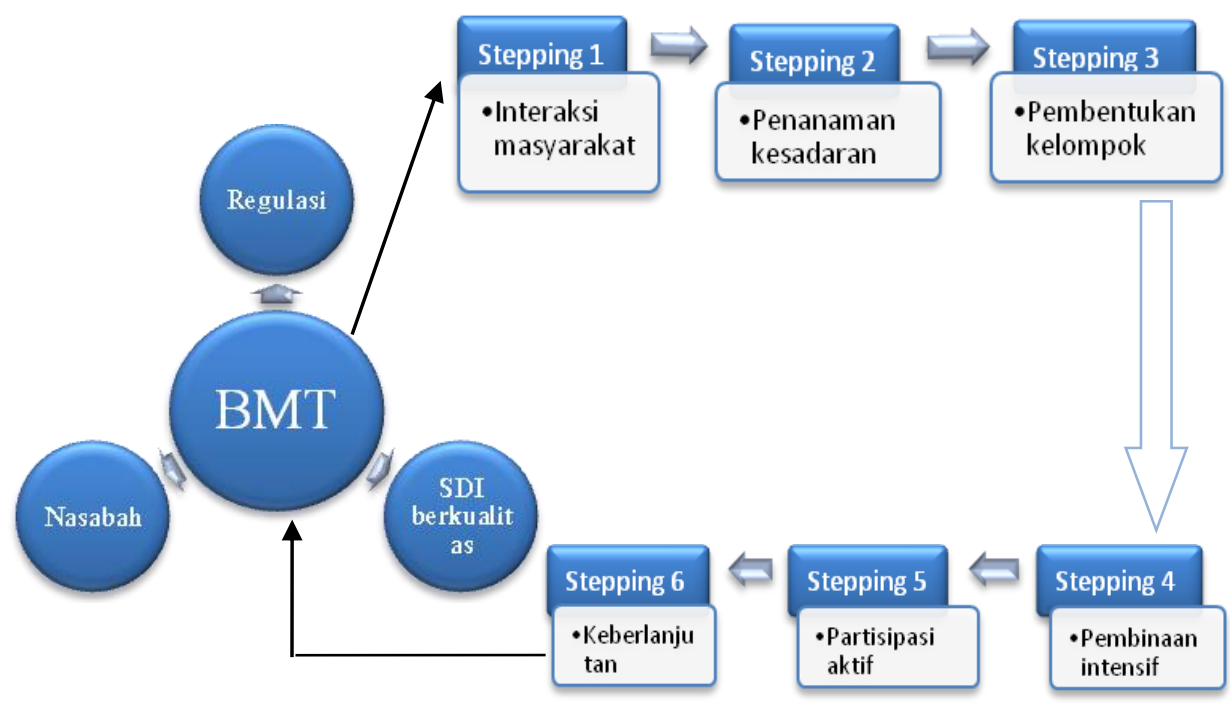

Gambar 1. BMT dan stepping pemberdayaan

Untuk menciptakan pemberdayaan, semua stakeholders BMT harus memiliki pemikiran yang sama tentang pemberdayaan. Hal ini sesuai dengan pendapat Ginanjar Kartasasmita bahwa pemberdayaan merupakan upaya untuk membangun daya dengan mendorong, memberikan motivasi, dan membangkitkan kesadaran akan potensi yang dimilikinya serta berupaya untuk mengembangkannya. ${ }^{40}$ Demikian juga menurut Jim Ife, pemberdayaan dilakukan melalui

${ }^{40}$ Kartasasmita, Pembangunan, 19. 
peningkatan kesadaran dan pendidikan (education and consciousness raising). ${ }^{41}$

Agar BMT mampu melakukan pemberdayaan ekonomi masyarakat maka harus tersedia sumber daya insani yang berkualitas dan melakukan pembinaan secara bertahap terhadap nasabah yang telah tersegmentasi dengan baik. Gambaran teknis dari upaya pemberdayaan yang dilakukan oleh BMT Ar-Ridho adalah sebagai berikut.

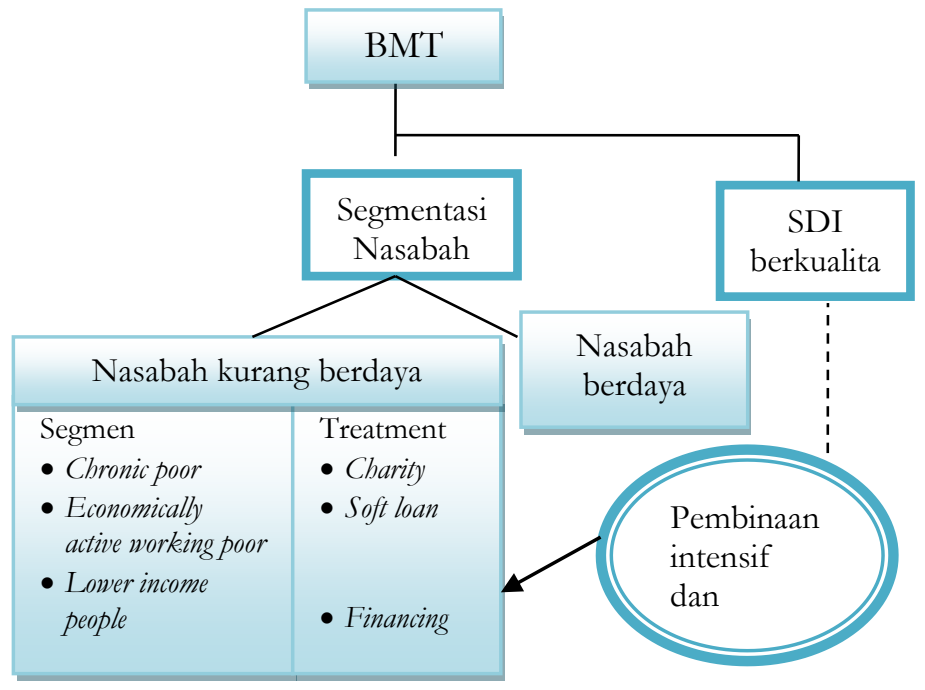

\section{Gambar 2.}

Pemberdayaan yang menekankan pembinaan dan SDI berkualitas

Dalam pemberdayaan, BMT menjalankan fungsi ganda yaitu sebagai lembaga intermediasi ekonomi dan sekaligus intermediasi sosial. Kedua fungsi ini sesuai dengan pendapat Huda dan Heykal yang menyatakan bahwa BMT melakukan kegiatan dua hal sekaligus, yaitu bayt al-mâl (bayt $=$ rumah, mâl $=$ harta) menerima titipan dana zakat, infaq, sadaqah, serta mengoptimalkan distribusinya sesuai dengan amanahnya, serta bayt al-tamwîl (bayt $=$ rumah, tamwîl $=$ pengembangan harta) melakukan kegiatan pengembangan usaha produktif dan investasi dalam meningkatkan kualitas ekonomi pengusaha mikro dan kecil dengan mendorong kegiatan menabung dan menunjang pembiayaan kegiatan ekonominya. ${ }^{42}$

\footnotetext{
${ }^{41}$ Ife, Community Development, 63.

${ }^{42}$ Huda dan Heykal, Lembaga Kenangan Islam, 363-364.
} 
Fungsi BMT Ar-Ridho lebih dekat pada fungsi coaching dan balancing terhadap nasabah. Aktivitas intermediasi yang dilengkapi dengan coaching dan balancing dapat dilihat dalam gambar berikut.

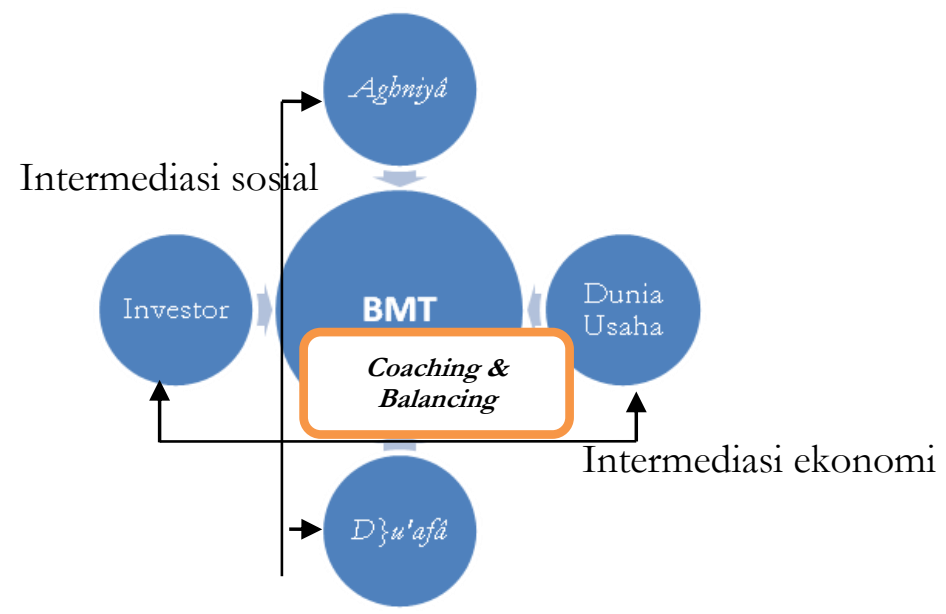

Gambar 3.

\section{Fungsi Intermediasi BMT plus Coaching and Balancing}

Fungsi coaching merupakan aktivitas pembinaan dan menyatu secara moral, spiritual dan gerak bersama dengan nasabah dalam memulai usaha, memasarkan, membangun jaringan hingga upaya menyisihkan penghasilan untuk ditabung sebagai modal mandiri. Kegiatan coaching dalam BMT sesuai dengan pendapat Hendi Suhendi bahwa BMT bertujuan menumbuhkan usaha-usaha produktif dan sekaligus memberikan bimbingan dan konsultasi bagi anggota di bidang usahanya dan meningkatkan wawasan dan kesadaran umat tentang sistem dan pola perekonomian Islam. ${ }^{43}$ Selain sebagai coaching, BMT Ar-Ridho juga menekankan pada pembiayaan jenis bagi hasil. Hal itu berarti BMT Ar-Ridho lebih mengedepankan balancing dalam bisnis, baik balancing dalam hal pembiayaan maupun balancing dalam hal model bisnis.

Dalam konteks nilai keislaman, fungsi intermediasi BMT juga menciptakan toleransi antara berbagai pihak dan lapisan masyarakat. Fungsi intermediasi ini juga untuk memudahkan pihak-pihak yang saling berkepentingan. Dalam hal ini Rasulullah pernah menyampaikan dalam hadîth yang diriwayatkan oleh Muslim dari Abû Hurayrah sebagai berikut.

43 Ibid. 


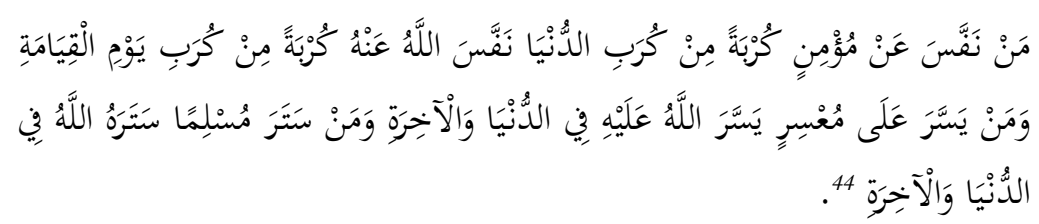

"Barang siapa yang melepaskan satu kesusahan seorang mukmin, niscaya Allah akan melepaskan darinya satu kesusahan pada hari kiamat. Barang siapa yang menjadikan mudah urusan orang lain, pasti Allah akan memudahkannya di dunia dan di akhirat".

Modal utama bagi BMT dalam melakukan optimalisasi fungsi intermedaisi adalah ketaatan pada prinsip sharî‘ah (sharia compliance) sehingga mendapat kepercayaan dari masyarakat untuk mengelola dana-dana sosial maupun dana-dana komersial. Gambaran teknis upaya intermediasi BMT secara optimal dalam pemberdayaan adalah sebagai berikut.

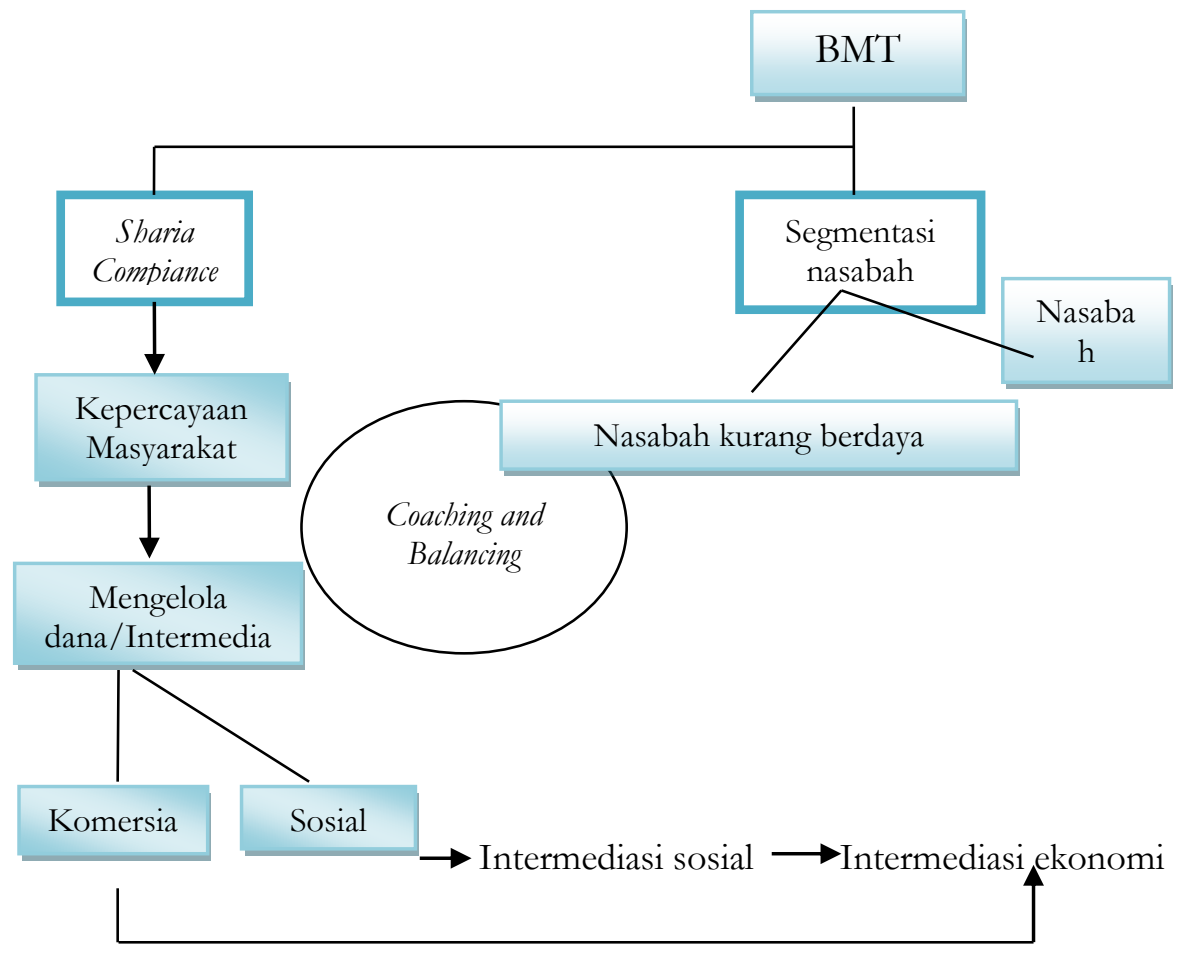

Gambar 4.

Upaya praktis optimalisasi fungsi intermediasi BMT

44 Șaḅ̂h Muslim nomor 2699. 
Kegiatan segmentasi nasabah yang terarah dan penguatan sharia compliance menjadi motivasi nasabah untuk bergabung dengan BMT Ar-Ridho tersebut. Menurut Max Weber, motivasi seseorang mengantarkan pada pilihan-pilahan tindakan sosial. Tipe tindakan sosial menurut Weber yang dikutip oleh George Ritzer dan Douglas J. Goodman ada empat yaitu: a) Tindakan rasionalitas instrumental (zwerk rational), yaitu suatu tindakan sosial yang dilakukan seseorang didasarkan atas pertimbangan dan pilihan sadar yang berhubungan dengan tujuan tindakan itu dan ketersediaan alat yang dipergunakan untuk mencapainya, b). Tindakan rasional nilai (werk rational) atau primordial, yaitu alat-alat yang ada hanya merupakan pertimbangan dan perhitungan yang sadar, sementara tujuannya sudah ada di dalam hubungannya dengan nilai-nilai individu yang bersifat absolut. Tindakan sosial tersebut telah dipertimbangkan terlebih dahulu karena mendahulukan nilai-nilai sosial maupun nilai agama yang dimiliki, c). Tindakan afektif (affectual action), yaitu tipe tindakan sosial yang lebih didominasi emosi tanpa refleksi intelektual atau perencanaan sadar. Tindakan afektif sifatnya spontan, tidak rasional, dan merupakan ekspresi emosional dari individu, d). Tindakan tradisional (traditional action), yaitu seseorang memerlihatkan perilaku tertentu karena kebiasaan yang diperoleh dari nenek moyang, tanpa refleksi yang sadar atau perencanaan. ${ }^{45}$

Motivasi nasabah BMT Ar-Ridho sebagian besar didasarkan pada pilihan rasional dan primordial. Berdasarkan hasil wawancara dengan pengelola BMT Ar-Ridho, sebagian besar nasabah memilih BMT ArRidho karena terdapat pembinaan nasabah, sementara pada BMT lainnya kegiatan pembinaan tersebut tidak berjalan. Selain itu jaringan bisnis yang dibentuk oleh BMT Ar-Ridho juga menjadi pertimbangan nasabah. Artinya, motivasi nasabah memilih BMT Ar-Ridho adalah karena pertimbangan rasionalitas. ${ }^{46}$ Selain itu, banyak nasabah yang menjadikan pertimbangan sharia compliance sebagai motivasi untuk memilih BMT Ar-Ridho. Hal berarti pilihan ideologis dan primordial juga menjadi motivasi nasabah untuk memilih BMT Ar-Ridho. ${ }^{47}$ Dengan demikian pola kerja BMT Ar-Ridho dalam fungsi intermediasi ekonomi dan sosial di masyarakat dilakukan dalam pola

\footnotetext{
45 George Ritzer dan Douglas J. Goodman, Teori Sosiologi, terj. Nurhadi (Yogyakarta: Kreasi Wacana, 2008), 136-138.

${ }^{46}$ Ika Erlinawati, Wawancara, Trenggalek, 16 April 2015.

${ }^{47} \mathrm{Ibid}$
} 
kerja rasional dan motivasi nasabah juga rasional serta ideologis primordial.

Selanjutnya BMT Ar-Ridho melakukan kebijakan pembiayaan dengan beberapa cara, antara lain: a). segmentasi nasabah dan pembiayaan berjenjang, b). pembinaan nasabah dalam kelompokkelompok, dan c). teknik tabungan terkoordinir.

Kegiatan segmentasi nasabah beserta treatment pembiayaan dapat dilihat dalam tabel berikut.

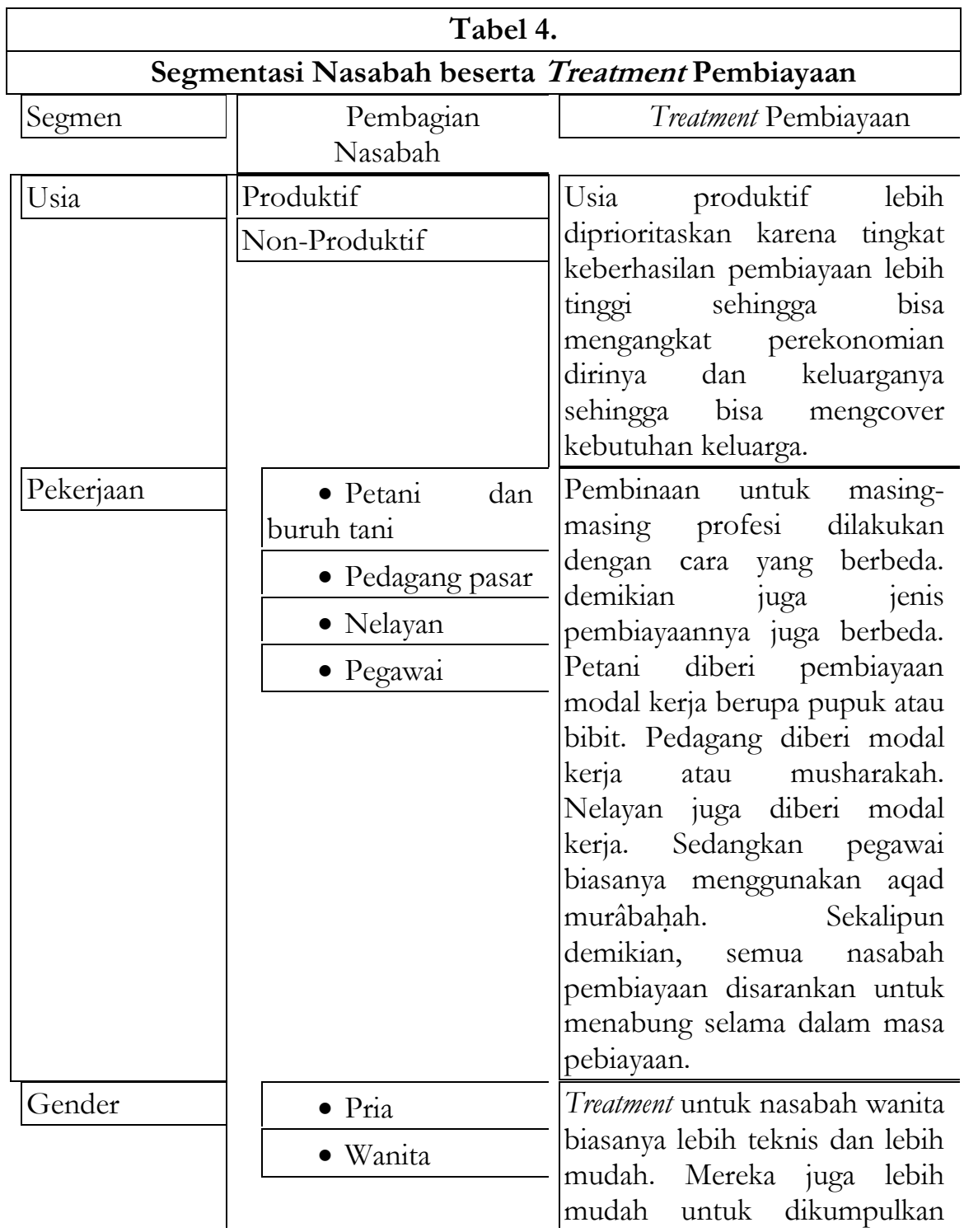




\begin{tabular}{|c|c|c|}
\hline & & $\begin{array}{l}\text { dalam pembinaan usaha kecil. } \\
\text { Sedangkan treatmen untuk } \\
\text { nasabah pria biasanya lebih } \\
\text { mengedepankan sharing } \\
\text { pendapat. }\end{array}$ \\
\hline \multirow{5}{*}{$\begin{array}{l}\text { Tempat } \\
\text { Tinggal }\end{array}$} & - Pesisir & \multirow{5}{*}{$\begin{array}{l}\text { Nasabah } \quad \text { pesisir } \\
\text { pegunungan dan } \\
\text { komunal. Sedangkan nasabah } \\
\text { pasar dan pegawai lebih } \\
\text { mengedepankan pembinaan } \\
\text { model face to face, sendiri- } \\
\text { sendiri. }\end{array}$} \\
\hline & - Pasar & \\
\hline & - Desa & \\
\hline & - Pegunungan & \\
\hline & & \\
\hline \multirow[t]{5}{*}{$\begin{array}{l}\text { Penghasilan/ } \\
\text { tingkat } \\
\text { perekonomian }\end{array}$} & $\begin{array}{l}\text { - Belum mampu } \\
\text { (tidak berdaya, mau } \\
\text { berdaya, }\end{array}$ & \multirow{5}{*}{ 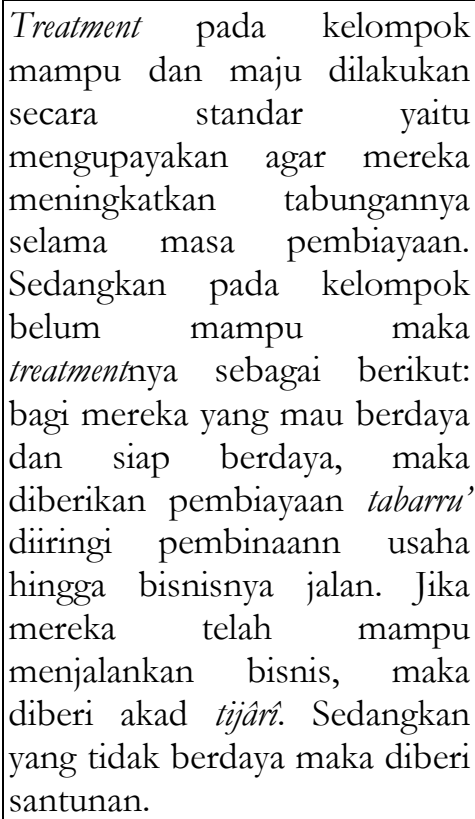 } \\
\hline & berdaya) & \\
\hline & - Mampu & \\
\hline & - Maju & \\
\hline & & \\
\hline
\end{tabular}

Sumber: Modifikasi peneliti, 2014.

Proses treatment pembiayaan menuju pemberdayaan terhadap masyarakat miskin dibedakan menjadi tiga segmen, yaitu kelompok belum mampu, kelompok mampu dan kelompok maju yang diilustrasikan dalam gambar berikut ini:

Treatment pembiayaan masyarakat miskin 


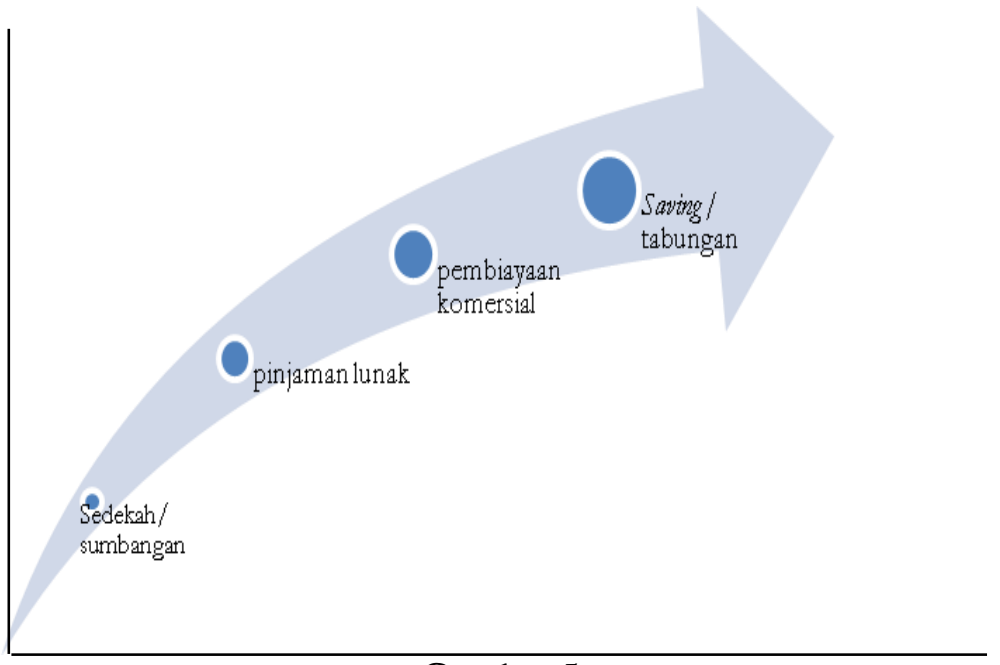

\section{Gambar 5.}

Treatment pembiayaan berjenjang bagi masyarakat miskin menuju pemberdayaan

Berdasarkan gambar tersebut, proses pemberdayaan masyarakat miskin diawali dengan sumbangan yang diambilkan dari dana zakat, infaq, sadaqah, wakaf dan hibah diiringi dengan pembinaan intensif tentang pemahaman potensi diri, kewirausahaan dan sikap-sikap positif dalam perekonomian dan sosial. Selanjutnya ketika mereka telah memiliki jiwa kewirausahaan dan sikap diri yang positif, maka pinjaman lunak dapat diberikan dengan terus dilakukan pembinaanpembinaan. Manakala mereka telah produktif, maka pembiayaan komersial dapat diberikan hingga mereka mampu melakukan saving.

Pemberdayaan masyarakat menengah ke bawah, terutama kepada nasabah produktif, dapat dilakukan dalam tiga kegiatan sekaligus, yaitu pembiayaan, pembinaan dan pemasaran produk atau jasa. Pedagang kecil atau masyarakat menengah ke bawah dalam memeroleh pembiayaan untuk memerluas usaha atau membangun usaha baru biasanya relatif sulit, maka BMT dapat berperan dalam pembiayaan tanpa menghilangkan unsur kehati-hatian dalam penyaluaran pembiayaannya. Selanjutnya para pedagang kecil dan masyarakat menengah ke bawah dalam melakukan usahanya agar mampu memertanggungjawabkan pembiayaannya, maka BMT memberikan pembinaan kewirausahaan maupun pengelolaan keuangan. Bentuk pembinaan dapat dilakukan dengan cara mengadakan seminar ataupun pelatihan agar nasabah mampu meningkatkan keterampilan yang dimilikinya. Dalam pembinaan ini, BMT dapat melakukan 
pelatihan kewirausahaan untuk masyarakat umum sehingga membangkitkan semangat berwirausaha. Dengan demikian program pembinaan dapat memberikan peningkatan jumlah penyaluran dana BMT, seiring dengan meningkatnya jumlah penerima pembiayaan yang telah mendapatkan pembinaan terlebih dahulu.

Tantangan terbesar BMT Ar-Ridho sebenarnya adalah menjadikan pada diri nasabah mau dan mampu menciptakan tabungan sehingga kehidupannya lebih berdaya dan tetap berpola hidup sesuai dengan kemampuannya. Di sinilah diperlukan perencanaan keuangan oleh nasabah yang dipandu oleh BMT. Urgensi BMT dalam memandu tabungan nasabah dalam bentuk tabungan terkoordinir atau tabungan kotak adalah karena biasanya seseorang cenderung untuk tidak punya niat yang kuat untuk menyisihkan penghasilannya untuk ditabung. Jika ada pihak lain yang sedikit memaksa dengan sebuah sistem yang disepakati sebelumnya, biasanya seseorang akan melakukan perencanaan yang lebih matang dalam menyisihkan penghasilannya untuk ditabung. Oleh karena itu BMT Ar-Ridho menetapkan tabungan terkoordinir yang telah dilakukan sejak awal mula pendirian BMT Ar-Ridho sekitar 14 tahun yang lalu.

Mekanisme pembiayaan harus mampu mengangkat harkat dan martabat kaum miskin menjadi lebih berdaya. Salah satu upaya untuk menciptakan pemberdayaan ini adalah dibudayakannya kebiasaan menabung dari nasabah yang mendapatkan pemberdayaan. Islam memerintahkan untuk memersiapkan keadaan yang akan datang. Di dalam Q.S. al-Ḥashr [59]: 18 disebutkan yang artinya:

"Hai orang-orang yang beriman, bertakwalah kepada Allah dan hendaklah setiap diri memerhatikan apa yang telah diperbuatnya untuk hari esok: dan bertakwalah kepada Allah, sesungguhnya Allah Maha Mengetahui apa yang kamu kerjakan".

Oleh karena itu BMT yang memiliki arah pemberdayaan harus memerhatikan setiap pembiayaan yang dikeluarkannya dengan memerhatikan strategi, teknis, akad yang digunakan, termasuk fungsi pembiayaan yang akan diperankannya. Pembiayaan yang terarah akan mampu menyelesaikan masalah-masalah ekonomi nasabah sehingga berdampak pada peningkatan kesejahteraan nasabah. Selanjutnya dana-dana sosial yang diatur sedemikian rupa dalam pembiayaan berjenjang beserta pembinaannya, juga akan menyelesaikan masalahmasalah sosial.

48 al-Qur'ân, 59: 18. 
Mekanisme pembiayaan yang tepat untuk nasabah BMT dilakukan dengan pendekatan kelompok karena proses penguatan ekonomi yang modern dan efisien, tidak dapat dilakukan melalui pendekatan individu, tetapi pendekatan kelompok. Keuntungan pendekatan kelompok tersebut adalah jika salah satu dari anggota kelompok tersebut mengalami keberdayaan, maka akan memberi imbas pada anggota kelompok yang lain. Berkaitan dengan kekuatan kelompok ini, Kats mengatakan bahwa beberapa point yang dicapai oleh anggota kelompok dalam suatu organisasi akan menguatkan anggota kelompok lainnya. ${ }^{49}$ Dengan demikian mekanisme pembiayaan yang mengarah pada pemberdayaan yang efisien dan modern harus mengedepankan pendekatan kelompok.

Pembiayaan yang terencana, berjenjang dan diikuti pembinaan akan menghasilkan entrepreneur-entreprenuer baru yang memiliki karakter bisnis yang islami. Oleh karena itu pembiayaan yang baik juga akan berfungsi secara etika, yaitu adanya pendidikan karakter di dalam pembiayaan tersebut sehingga muncul pebisnis islami yang bermoral.

Di antara karakter pebisnis yang bermoral adalah mereka yang konsisten dengan kebenaran, amanah, mawas diri dan bertanggung jawab. Dalam konteks nilai keislaman, pebisnis islami yang bermoral diperintahkan oleh Islam seperti disebutkan dalam Q.S. al-Mu'minûn [23]: 8 yang artinya:

"Dan orang-orang yang memelihara amanat-amanat (yang dipikulnya) dan janjinya". ${ }^{50}$

Pebisnis yang memiliki etika akan senantiasa menjaga amanat yang dibebankan kepada dirinya, di antaranya tidak berbuat curang atau melakukan penipuan. Pebisnis yang beretika juga senantiasa menjaga kepatuhan kepada prinsip sharî́ah yang merupakan hal fundamental bagi BMT dan akan berimbas kepada produk dan transaksinya. Jika sharia compliance tidak terlaksana di suatu BMT, maka keberkahan transaksi dalam BMT tersebut juga hilang karena keberkahan pada dasarnya terjadi manakala dilakukan dalam bingkai ketaatan kepada Allah.

Untuk menciptakan kepatuhan kepada prinsip sharî‘ dibutuhkan komitmen yang tinggi untuk menghasilkan kinerja yang maksimal. Penelitian Johanis W Kiuk menunjukkan bahwa ada

49 R Katz, "Empowerment and Synergy: Expanding the Community's Healing Resources", Prevention in Human Services, Vol. 3 (Winter-Spring, 1984), 201-225.

50 al-Qur'ân, 23: 8. 
hubungan antara komitmen dengan kinerja. ${ }^{51}$ Oleh karena itu managemen BMT Ar-Ridho menekankan komitmen terhadap kepatuhan pada prinsip sharî́ah ini kepada semua stakeholders BMT.

Dengan mekanisme pembiayaan BMT yang amanah, maka secara psikologis akan menumbuhkan kenyamanan beraktivitas dan bertransaksi, baik bagi masyarakat yang akan berhubungan dengan BMT, maupun pihak pengelola dan pengurus yang menjalankan operasional BMT. Hal ini akan meminimalisir kesalahan dan penyimpangan yang mungkin terjadi, dan meningkatkan optimisme masyarakat terhadap peran BMT dalam menunjang pemberdayaan ekonomi masyarakat dalam koridor kepatuhan terhadap prinsip sharî‘ah. Dengan demikian, segala aktivitas BMT harus tetap dibingkai dalam koridor kepatuhan pada prinsip sharî‘ ah agar mendapatkan keberkahan. Ismail Nawawi menyampaikan bahwa segala aktivitas ekonomi harus berlandaskan nilai-nilai iman, keahlian, keseimbangan, keadilan dan kemaslahatan serta konsistensi ketekunan untuk melepaskan diri dari segala kemaksiatan dan perbuatan dosa. ${ }^{52}$

Dengan demikian antara pemberdayaan ekonomi masyarakat, fungsi intermediasi BMT, dan mekanisme pembiayaan yang dilakukan oleh BMT tidak dapat dipisahkan satu dengan lainnya. Ketiga unsur tersebut saling terkait dan saling menunjang. Tidak berfungsinya salah satu unsur tersebut mengakibatkan tidak optimalnya pemberdayaan ekonomi masyarakat yang dilakukan oleh BMT. Keterkaitan pemberdayaan ekonomi masyarakat, fungsi intermediasi BMT dan mekanisme pembiayaan BMT diilustrasikan dalam gambar berikut ini.

\footnotetext{
${ }^{51}$ Johanis Kiuk, "Kinerja Pemasaran: Antesendens dan Konsekwensi Sebuah Model Teoritikal Dasar, Jurnal Sains Pemasaran Indonesia, Vol. 5, No. 1 (2007), 1-40.

52 Ismail Nawawi, Pembangunan dalam Perspektif Islam: Kajian Ekonomi, Sosial, dan Budaya (Surabaya: Putra Media Nusantara, 2009), 110.
} 


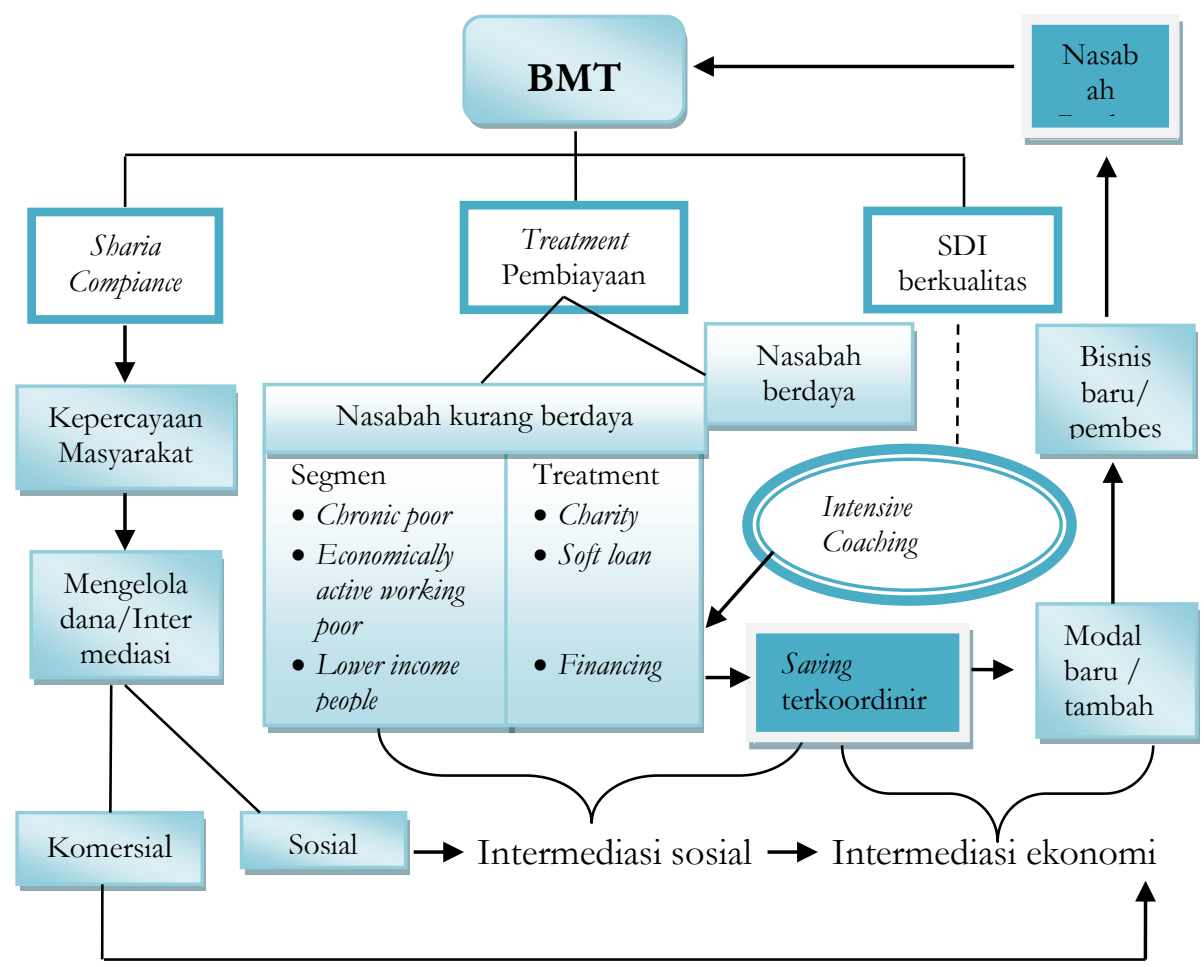

Gambar 6.

Model pemberdayaan ekonomi masyarakat melalui BMT

Berdasarkan gambar di atas dapat dijelaskan sebagai berikut.

1. BMT mengedepankan kepatuhan pada prinsip sharî́ah (sharia compliance) sehingga menjadi salah satu faktor kepercayaan masyarakat, baik dari pihak penabung, investor, maupun pihak pembiayaan. Pengelolaan dana-dana komersial telah mengantarkan peran BMT pada fungsi intermediasi ekonomi yang nyata di masyarakat. Sedangkan pengelolaan dana sosial mengantarkan BMT pada fungsi intermediasi sosial. Fungsi intermediasi sosial ini dapat diteruskan ke fungsi intermediasi ekonomi manakala nasabah yang mendapatkan jasa keuangan sosial tersebut telah beralih menjadi nasabah berdaya yang disebabkan oleh pembinaan yang dilakukan oleh BMT.

2. BMT harus melakukan segmentasi nasabah pembiayaan beserta treatment pembiayaannya. Harus dibedakan nasabah yang telah berdaya, yaitu nasabah pembiayaan yang telah memiliki bisnis yang 
mapan, skill yang memadai, jiwa entrepreneur yang handal dan sebagainya dengan nasabah yang masih belum berdaya. Nasabah belum berdaya yang benar-benar miskin dan belum mempunyai kemampuan kerja (chronic poor) maka treatment yang digunakan adalah memberi santunan (charity) dengan pembinaan dan motivasi sehingga tertanam jiwa dan pikiran positif untuk bangkit. Sedangkan nasabah belum berdaya yang sudah punya penghasilan namun masih masuk kategori miskin (economically active working poor), maka treatment yang digunakan adalah memberi pinjaman lunak (soft loan) dengan pembinaan motivasional dan pembinaan manajerial intensif sehingga tumbuh jiwa entrepreneur mereka. Sedangkan nasabah belum berdaya yang sudah punya penghasilan namun masih belum mampu mencukupi kebutuhannya (lower income), maka treatment yang digunakan adalah memberi pinjaman lunak (soft loan) dan secara bertahap diberi pembiayaan komersial dengan pembinaan motivasional dan pembinaan manajerial intensif sehingga tumbuh jiwa entrepreneur mereka serta mulai berani membuka relasi bisnis dengan dunia luar. Jika mereka telah mendapatkan pembinaan secara terus menerus, maka mereka akan berdaya dan sudah bisa diberikan pembiayaan komersial (financing) dengan terus dilakukan pembinaan. Selanjutnya bagi nasabah kurang berdaya yang telah bergeser menjadi nasabah berdaya diberlakukan treatment tabungan terkoordinir. Dengan saving yang dimiliki oleh nasabah, maka menciptakan modal baru atau tambahan modal sehingga mengarah pada penciptaan bisnis baru atau perbesaran bisnis nasabah. Jika kondisi tersebut telah terjadi, maka keberdayaan nasabah benar-benar telah terwujud. Keberdayaan nasabah akan menunjang operasional BMT karena nasabah tersebut akan memasukkan dananya ke BMT. Dengan demikian likuiditas BMT dapat lebih terjamin.

3. Untuk menciptakan optimalisasi operasional BMT diperlukan sumber daya insani yang berkualitas, terutama dimulai dari berkualitasnya sumber daya insani pengelola BMTsehingga mengantarkan pada kepercayaan masyarakat dan bisa melakukan pembinaan kepada nasabah. Pembinaan motivasional diarahkan pada nasabah yang belum berdaya sedangkan pembinaan bisnis dilakukan pada nasabah yang belum berdaya maupun nasabah yang telah berdaya hingga pembinaan yang mengarah pada saving. 


\section{Penutup}

Pemberdayaan ekonomi masyarakat yang dilakukan oleh BMT melibatkan tiga unsur utama pemberdayaan, yaitu strategi pemberdayaan, teknik pemberdayaan, dan pengondisian pemberdayaan. Ketiga unsur pemberdayaan tersebut diimplementasikan dengan aktivitas riil berupa segmentasi nasabah yang telah berdaya dan yang belum berdaya, treatment pembiayaan berjenjang, pembinaan intensif, penyediaan sumber daya insani yang memahami visi dan misi pemberdayaan, optimalisasi fungsi intermediasi ekonomi dan intermediasi sosial, serta motivasi dan penyediaan sarana menabung terkoordinir. Pemberdayaan ekonomi masyarakat oleh BMT dilakukan melalui stepping yang teratur dan terarah, sebagai berikut: a) interaksi intensif dengan masyarakat sekitar, b) penanaman kesadaran atau kesamaan pikiran, c) pembentukan kelompokkelompok terkoordinir, d) pembinaan intensif, e) partisipasi aktif, dan f) pelaku aktif dalam keberlanjutan pemberdayaan. Dengan demikian BMT sejak awal harus menetapkan visi dan misi pemberdayaan serta mengedepankan dialog kepada masyarakat untuk menemukan problem dan solusi dari masyarakat sendiri. Managemen BMT sebaiknya menyediakan sumber daya insani yang memahami visi misi pemberdayaan ekonomi masyarakat.

Pola kerja BMT adalah pola kerja rasional. Motivasi nasabah mengarah pada pertimbangan tindakan rasional dan ideologis primordial, bukan afektual maupun tradisional. Fungsi intermediasi ekonomi dan intermediasi sosial BMT dilakukan dengan pengembangan potensi ekonomi umat, peningkatan kualitas sumber daya insani, perantara aghniyâ dan dú 'afâ', perantara pemilik dana dan pengguna dana. Fungsi BMT bukan sekedar sebagai mitra atau lembaga intermediasi saja, namun lebih dekat pada fungsi coaching terhadap nasabah. BMT juga menekankan pada pembiayaan jenis bagi hasil untuk mengimbangi banyaknya pembiayaan dengan pola jual beli atau murâbahah. Oleh karena itu managemen BMT harus membuat panduan pembinaan yang terarah kepada nasabah sehingga fungsi coaching dan balancing BMT dapat terlaksana dengan baik.

\section{Daftar Rujukan}

Akhtar, M. R. " Practice and Prospects of Musharaka Financing for Small Entreprise in Pakistan", Journal of Islamic Banking in Finance, Vol. 13, No. 3, 1996. 
Baydâwîi (al), Nâṣir al-Dîn Abû Saî̀d 'Abd Allâh b. 'Umar b. Muhammad al-Shîrâzî. Anwâr al-Tañîl wa Asrâr al-Ta'wîl, Vol. 3. Beirut: Muassasah Sha'bân, t.th.

Al-Harran, S. "Islamic Finance Needs A New Paradigm", New Horizon, Vol. 48, Feb, 1990.

Bâqî (al), Fu'âd 'Abd. Mu'jam al-Mufahras li Alfâz al-Qur'ân al-Karîm. Beirut: Dâr al-Fikr, 1981.

Behdad, Sohrab. "Property Rights in Contemporary Islamic Economic Thought: A Critical Perspective", Review of Social Economy, Summer, Vol. 47, No. 2, 1999.

Dahl, Robert. Democracy and Its Critics. New Haven Conn: Yale University Press, 1983.

Dhumale, R., dan Sapcanin, A. An Aplication of Islamic Banking Principles to Microfinance. United Nations Development Program, Regional Bureau for Arab States, New York, 1998.

Drijver, C. dan Sajise, P. Community-Based Resource Management and Environmental Action Research, dalam Proceedings of the Experts' Workshop on Community Based Resource Management: Perspectives, Experiences and Policy Issues, Los Banos, Philippines (UPLB), Environmental and Resource Management Project \& UPLB., 1993.

el-Gamal, Mahmoud A. Islamic Finance: Law, Economic, and Practice. Cambridge: Cambridge University Press, 2006.

El-Komi, Mohammed., dan Groson, Rachel. "Experiments in Islamic Microfinance", Journal of Economic Behavior and Organization, Vol. 83, No. 2, 2012.

Fatwa DSN No: 15/DSN-MUI/IX/2000 tentang Prinsip Distribusi Hasil Usaha dalam LKS.

Friedmann, John. Empowerment: the Politics of Alternative Development. Cambridge Mass: Blackwell Publisher, 1992.

Gruber, J. dan Trickett, E.J. "Can We Empower Others? The Paradox of Empowerment in the Governing of an Alternative Public School", American Journal of Community Psychology, Vol. 15(3), 1987.

Huda, Nurul., dan Heykal, Muhammad. Lembaga Kenangan Islam: Tinjauan Teoritis dan Praktis. Jakarta: Kencana Prenada Media Group, 2010.

Hulme, David., dan Turner, M. Sociology of Development: Theories, Policies, and Practices. Hertfordshire: Harvester Whearsheaf, 1990. 
Ife, Jim. Community Development: Creating Community Alternatives-Vision, Analysis and Practice. Australia: Longmann, 1995.

Ilmi SM, Makhalul. Teori dan Praktek Lembaga Mikro Keuangan Syariah. Yogyakarta: UII Press, 2002.

Jawharî, Tanțâwî. al-Jawâhir fî Tafsîr al-Qur'ân al-Karîm. Damaskus: Dâr al-Fikr, t.th.

Karim, Adiwarman. Bank Islam Analisis Fiqib dan Kenangan. Jakarta: RajaGrafindo, 2004.

Kartasasmita, Ginanjar. Pembangunan untuk Rakyat. Jakarta: Pustaka Gramedia, 1995.

Katz, R. "Empowerment and Synergy: Expanding the Community's Healing Resources," Prevention in Human Services, Vol. 3, WinterSpring, 1984.

Kieffer, C. H., Citizen Empowerment: A Developmental Perspective, Prevention in Human Service, Vol. 3, USA, 1984.

Kiuk, Johanis. "Kinerja Pemasaran: Antesendens dan Konsekwensi Sebuah Model Teoritikal Dasar, Jurnal Sains Pemasaran Indonesia, Vol. 5, No. 1, 2007.

Kondalkar, V.G. Organizational Behaviour. New Delhi: New Age International Publisers, 2007.

Korten, David C. People Centered Development: Reflections on Development Theory and Methods. Manila: ADB, 1992.

Lewin, Kurt. Field Theory in Social Science: Selected Theoretical Papers. D. Cartwright (ed.). New York: Harper dan Row, 1951.

Nawawi, Ismail. Pembangunan dalam Perspektif Islam: Kajian Ekonomi, Sosial, dan Budaya. Surabaya: Putra Media Nusantara, 2009.

Nyadin, "Prospek Bisnis di Koperasi Jasa Keuangan Sharî‘ah Baitul Mal Wa Tamwil dan Peluang Kerja Bagi Alumni Program Ekonomi Sharî‘ah", Makalah dipresentasikan di IAIN Sunan Ampel Surabaya, 27 Desember 2011.

Paul, Samuel. "Community Participation in Development ProjectsThe World Bank Experience", dalam M. Bamberger (compiler), Readings in Community Participation, Vol. 1. The Economic Development Institute of the World Bank, Washington, DC, 1986.

Pusat Inkubasi Bisnis Usaha Kecil. BMT sebagai Alternatif Model Lembaga Kenangan Mikro: LKM. Jakarta: Pusat Inkubasi Bisnis Usaha Kecil, t.th. 
Pranarka, A.M.W., dan Moeljarto, Vidhyandika. Pemberdayaan: Konsep, Kebijakan, dan Implementasi. Jakarta: CSIS, 1996.

Ritzer, George., dan Goodman, Douglas J. Teori Sosiologi, terj. Nurhadi. Yogyakarta: Kreasi Wacana, 2008.

Simon, B.L. "Rethinking Empowerment", Journal of Progressive Human Services, Vol. 1(1), 1990.

Sumber: Dokumen BMT Ar-Ridho Trenggalek 2014.

Sumber: Neraca BMT Ar-Ridho per 30 Nopember 2014.

Sumiyanto, Ahmad. BMT Menuju Koperasi Modern. Solo: ISES Publishing, 2008.

Sutrisno. Menuju Masyarakat Partisipatif. Yogyakarta: Penerbit Kanisius, 2005.

Yamanî (al), Muhammad b. 'Alî b. Muḥammad b. 'Abd Allâh alShawkânî. Fath al-Qadîr, Vol. 5. Damaskus: Dâr Ibn Kathîr, 1994.

\section{Wawancara}

Erlinawati, Ika. Wawancara. Trenggalek, 12 Desember 2014.

-----. W awancara. Trenggalek, 16 April 2015.

Hardina. Wawancara. Trenggalek, 12 Desember 2014.

Saputra, Hardina. Wawancara. Trenggalek, 18 Desember 2014. 